\title{
Infusing the Concept of Aqil Baligh for Early Childhood
}

\author{
Wahidah \\ English Department, Institut Agama Islam Negeri Langsa, Indonesia \\ wahidah@iainlangsa.ac.id
}

$\begin{array}{ccc}\text { First received: } & \text { Revised: } & \text { Final Accepted: } \\ \text { February 28, 2021 } & \text { Mai 25, 2021 } & \text { June 24, 2021 }\end{array}$

\begin{abstract}
The article discusses the concept of teaching and learning aqil baligh in early childhood and given the importance of one readiness in carrying out one duty as a mukallaf when it has reached aqil baligh. Teaching and learning aqil baligh for early age children is not a provision of obligations but rather a preparation, training and habituation to welcome the period of imposition of obligations (taklif) when he is baligh later. This is a qualitative research based on a literature review. Data collection of this study was from books, journals of research results related to early childhood education. Early childhood education (between 0- 7 years) emphasizes the attainment of one's awareness of carrying out orders and abandoning the prohibitions of God. Learning material includes aqidah, worship (ibadah), and morals (akhlak) with several models. Early Childhood Education teachers must develop and model it for the children.
\end{abstract}

Keywords: Aqil Baligh, Early Childhood, Teaching and Learning

Corresponding Author:

English Department

Institut Agama Islam Negeri Langsa, Indonesia

Email: wahidah@iainlangsa.ac.id 


\section{INTRODUCTION}

Teaching and learning are a set of actions designed to support the learning process. Learning is intended to produce learning designed in such a way as to activate, support, and sustain the process while learning happened (Siregar \& Nara, 2010). Learning at an early age will make a fundamental and deep mark for a human being. Early childhood education is useful in preparing people to have aqil baligh as desired by Islam. Islam wants each able to achieve happiness in the world and the hereafter. The most important happiness must be found in the life to come (Rizal \& Zuhri, 2006).

Ibn Al-Qayyim as quoted by Salati (2012) reminded that "whoever leaves his child uneducated and leaves him without getting anything, he has committed the peak of crime". Leaving children without a good education is robbing them of their future. When children at an early age do not get a good education, they will have a bad character. Later it will make parents regret their child's deviant behaviour due to mistakes in educating them in childhood.

Islam emphasizes the importance of education for a child from birth, especially at the initial age of six years. It is to provide an educational stimulus to help the growth and development of children both physically and spiritually. In this case, the children have readiness when they reach the age of adulthood. A continuous and directed learning process or practice must be carried out so that children can bear the burden of shari'ah (mukallaf), be independent or mature mentally, spiritually, emotionally, and even financially when they reach the age of 14-15 years (Santosa, 2018).

Aqil baligh education is a set of actions designed to instill an awareness of human responsibility. Inculcating the value of responsibility in early childhood by training to be responsible for what they do. For example, after playing they are directed to tidy up their toys or use something that has been tidied up and put back in place when it is finished. It is the same in instilling disciplinary values in the field of worship, for example, such as Dhuha prayer, recitation, and Zuhr prayer according to a predetermined time (Bahfen et al., 2020). Early childhood education focuses on laying the foundation towards physical growth and development, intelligence, socio-emotional, language, and communication. This level of education is adjusted to the uniqueness and stages of development that early childhood goes through (Pires, 2018).

Coaching and providing educational materials for early childhood is divided into two phases, including calling the call to prayer in the baby's ear, giving a good name, and caring for the child. Education carried out in this infant phase is physical education, spiritual education, and intellectual education (reason). As for the childhood phase (0 - 6) the education provided is further education from the infant phase. It is given in the form of educational stimulation in order to optimize children's development (Salati, 2012). Encouragement is carried out by adjusting the characteristics of children who are unique individuals, who have experiences and knowledge that are different from other people (Suradi, 2018).

Early childhood education has a very decisive purpose and essence for the formation of a child's personality when reaching aqil baligh. According to Hidayat et al. (2018) the essence of early childhood education is the formation of self-awareness and noble 
personality based on the child's identity and potential as learners according to Islamic education teachings. Humans who are able to be responsible to serve the Creator as mentioned in the Koran Surah Adz-Dzariat verse 56 "And I (Allah) did not create jinn and humans but to worship Me".

The author has not found the study of the process of learning aqil baligh, but the discussion of aqil baligh education already exists but is still very limited. Most of the studies focus on the habituation of ibadah (Jasuri, 2015; Wahab, 2018; Zulfa, 2014). Research related to aqil baligh is Aynun research (2018) discusses pre-aqil baligh education and Wahidah (2020) which discusses aqil baligh education in elementary schools and steps its application. However, it has not been found about how to prepare aqil baligh for early childhood. So this study is a development of existing studies by examining the concept of learning that prepares aqil baligh phase for early childhood. This study will explain the concept of aqil baligh and the importance of preparations that need to be done at the age range of 5-6 years. Then offer materials and learning models that are suitable for preparing children in the phase of aqil baligh.

\section{METHOD}

This study focuses on how to apply the concept of teaching and learning aqil baligh for early childhood using the literature review method as the source of the data. Data was taken from various written sources, including seven books, eighteen journal articles, and one proceeding article. Furthermore, it is classified according to the needs, adapted and summarized, and then analyzed to be developed in the academic discussion in writing this article. The approach to research is a reflective one that stems from the author's personal experience and understanding search for its essence looks for its meaning and continue to develop its thoughts which are enriched with thoughts or theories from scientists and previous research (Muhadjir, 1996, p. 93).

\section{FINDINGS AND DISCUSSION}

The word aqil shows the potential of a person who is healthy, has a perfect mind, can distinguish good and bad, right and wrong, knows and understands obligations, knows which rules are permissible and which are prohibited. Understand what is beneficial and what is destructive, have awareness, and act without pressure. Aqil is associated with the ability to reason, not with physical biology. A person does not have the power of reason when he is a child. However, it will grow when someone gets an appropriate education. However, the ability to reason sinks again when entering the elderly which is marked by weakness in remembering. The power of reason can also be lost while sleeping, drunk or crazy (Aynun, 2018). It can be understood that aqil is a condition for achieving psychological maturity, socialization skills, financial independence, and the ability to bear sharia responsibilities.

According to Imam al-Ghazali (2020, pp. 170-171), the term Al-Aqil or 'aqil has four meanings according to the level of human development who has perfect intelligence. The first meaning of reason is a quality that distinguishes humans from animals. Intellect makes humans know and understand theoretical science. Intellect is likened to a light that infiltrates the human heart and helps him understand something. Second, the meaning of 
reason is wisdom that appears at an early age. For example, a child knows instinctively that two is greater than one and something that is lawful (permissible) is not the same as what is haram (prohibited). Third, the meaning of reason means knowledge obtained through experience. A rational person when he finds and gets lessons from the experience gained from time to time. Fourth, one is reasoned when a person's natural power reaches a stage where he is able to know the cause and effect of his actions. He also is able to control their sexual appetite. The level of reasoning at this stage aims to get the pleasure of Allah SWT.

Meanwhile, baligh has the meaning of reaching the condition of biological maturity which is marked by the maturity of the reproductive organs. It can also be interpreted as people who are old enough (Santosa, 2018). Aqil means the mature way of thinking and baligh is physically mature. Sensible maturity is where a person can take on roles and responsibilities as an adult. Meanwhile, physical maturity is when all bodily functions can function according to age stages. It is essential to balance between aqil and baligh so that every action and function of the body is balanced and can be accounted for.

From the explanation above, it is clear that the concept of aqil baligh in Islam is not only marked by physical changes, but also a sign of a shift in the phase of the child before compulsory sharia law and the phase after which is youth. So when someone reaches aqil baligh he is no longer called a child but is equal to adults in terms of worship, zakat, jihad, and others. For boys who have reached maturity, the scholars of figh agree that their parents are no longer obliged to support them. If there is a boy who has reach aqil baligh and still supported by his parents, then it is not actually a living but almsgiving. In doing so, Islamic education system must be able to prepare (especially boys) to be able to become mukalaf (people who are able to bear the Shari'a) when the timeaqil baligh comes.

Islamic legal experts such as Khallaf $(2002$, p. 215) define the criteria of aqil baligh as a requirement for a person to be called a mukallaf, that is, someone who knows or understands law and has reached a certain age to be burdened with sharia law (taklif). The terms "mukallaf" and "taklif" are found in Al-Qurán Surat al-Baqarah verse 286, namely the sentence "yukallifu" which means burden. So mukallaf is someone who already has the ability to take legal action so that Allah gives responsibility (burden) with the obligation to carry out all orders and stay away from all the prohibitions of Allah. Basically, the expertise or ability to carry out obligations is due to the reason, where the expertise is related to adult nature. A person becomes mature because of reason. So, a person who has reached maturity is considered wise and skilled in carrying out with perfect expertise.

In Islamic legal theory, the human life span is divided into two stages. The first stage is "Ahliyah al-wujub" (people who have no responsibility and only have rights); and the second stage is "Ahliyat al-ada" (the person who is responsible for implementing taklif). Each stage is further divided into two cycles of development. The first stage is divided into two development cycles, namely the al-ijtinani cycle (children in the womb) and the al-thufulah cycle (early childhood). While the second stage is divided into the al-tamyiz cycle (school age, 7-14 years) and the bulugh 'aqilan cycle (age of puberty, or maturity) (Fadlullah, 2017). 
In the concept of Islamic education, at the age of 15, it is called an adult who is able to accept full responsibility (taklif) in matters of worship, muamalat (business law), munakahah (marriage law) and jinayat (criminal law) at the latest at the age of 17 for women and 18 for men. At the age of 21 years, boys can be separated from their parents but must build closeness and still maintain obedience to their parents (Adzim, 2005, p. 7). Generally, children have reached maturity (menstruation) at the age of 10 to 12 years, therefore at the age of 10 to 14 years, this is the stage when children become aware or mature mentally, spiritually, emotionally, and even financially when they reach the age of 14 to 15 years old. At this stage, the child must be preoccupied with productive activities or projects and solutions according to their nature of uniqueness. In doing so, it is hoped there is not too much gap between baligh and aqil. As the social and educational systems of today are devastating, it persists from the age of 12 to 24 years. Various delinquencies and deviations from the younger generation are due to the gap between adolescence (biological adulthood) and aqil (mental adulthood) caused by the social system and the school system which slows down maturity through long infantilization (Santosa, 2018).

For that, learning must prepare the maturity of aqil baligh from an early age. So that at the age of adulthood a person with high awareness will be able to accept the responsibility of carrying out orders and leaving the prohibitions of Allah Almighty. A balanced learning process for early childhood with the method of singing, playing, and getting used to Islamic teaching material will create the pattern of a child's life that is desired in Islam. There are two signs of the arrival of the aqil baligh period, namely; first, with maturity characteristics such as menstruation for women or ihtilam (out of sperm), both men and women. Second, by reaching a certain age if the characteristics of maturity are not found in a person because there is a physical disorder, then the age of maturity is determined since 15 years, both male and female (Yahya \& Rahman, 1986, p. 168). The characteristic of aqil baligh is the ability to reason to carry out one's responsibilities as a mukallaf (the ability to bear and carry out responsibilities consciously). The process of aqil baligh education will make a person able to assume all responsibility for him both in words and deeds. Teaching the concept of aqil baligh is a conscious effort by both parents and Raudhatul Athfal teacher to provide the understanding and prepare children to take responsibility when they reach adulthood.

\section{Models of Teaching for Aqil baligh Concept}

Early childhood education is emphasized developing the totality of children's potential, including physical-motor, intellectual, moral, social, and emotional. Early childhood educators help children develop all their potential so that they develop towards the formation of whole humans who can function as independent humans (Aryani, 2015). The learning process determines the output of human resources that will play a role in society according to their potential. Many adults are formed from the influence of religious teachings and practices carried out in their childhood. Verbal exercises and ritualistic religious ceremonies (practices) are meaningful and are one of the characteristics of the level of religious development in children (Susiba, 2019).

The highest goal of education is to have the ability to actualize the full potential of humanity, both physically and spiritually. Able to carry out the function of servitude to Allah Almighty and the function of his caliphate in managing the universe for the 
prosperity of the inhabitants of the earth in order to achieve the welfare and happiness of life in the world and the hereafter (QS: Albaqarah verse 30). Hasan Langgulung (Langgulung, 2004, p. 56) concluded that the ultimate goal of education in Islam is the personal formation of a caliph for students. The characteristics of a caliph are having a fitrah, spirit, strong physique, free will, and reason. The task of education is to develop these four aspects in humans so that they can occupy the position of caliph. These objectives have been specifically included in Indonesia national education goals. Namely "developing the potential of students to become human beings who believe in and fear God Almighty, have noble character, are healthy, knowledgeable, capable, creative, independent, and become democratic and responsible citizens"(UU No. 20 Tahun 2003 Tentang Sistem Pendidikan Nasional, 2003).

Exploring the potential is actualized through learning which contains educational material that is planned in a planned manner for all students. Especially for early age students, of course, they have their own characteristics whose material content and learning methods are different from those of children who are teenagers and even adults. In another sense, learning is adjusted to the nature of human development, namely according to the stages of age 0-2 years, 2-7 years (pre-training), 7-10 years (pre aqil baligh 1), 11-14 (pre aqil baligh 2), and over 15 years (post aqil baligh) (Santosa, 2018). Each stage has its own golden period until it reaches adulthood. Teaching materials for early childhood must be in line with Islamic teachings with methods that are in accordance with the nature of their development.

There are three important materials to instill values and good characters of aqil baligh, namely; aqidah guidance, worship guidance and morals development material. First, the development of aqidah. It is religious knowledge to cultivate faith directly in the creator of Allah, His angels, His books, His messengers, the hereafter, and good and bad qadha and qadar. In the learning process, early childhood asks more questions about things they want to know. Prophet Muhammad (peace be upon him) taught us how to interact with children in terms of instilling the values of faith. It is narrated from Ibn Abbas that the Prophet said, which means "Teach the sentence Laa ilaaha illallah as the first sentence and guide them to Laa ilaaha illallah before their death." Abdurrazzaq reported that the friends liked to teach their children the phrase Laa ilaaha illallah as the first sentence they could recite fluently up to seven times, so this sentence became their first sentence. Ibnul Qayyim in his book Ahkam Al-Maulud, said, "when children begin to speak, it should be taught by guiding them the sentence Laa ilaaha illallah Muhammad Rasulullah and the first thing their ears heard was Ma'rifatullah (knowing Allah) and monotheizing it, and that Allah Almighty who is on His throne (arsy) always sees them, listens to their words, and He is always with them wherever they are (Suwaid, 2006).

Thabrani and Ibn Najr narrated from Ali what the Prophet said, which means "Teach your children about three things, love your Prophet, love his family, and recite the Koran. In fact, the carrier of the Qur'an is under the auspices of Allah's throne, on the day of where there is no shelter, except His shelter with the Prophets and His chosen people. " Imam Ghazali as quoted by Suwaid (Suwaid, 2006)The way to instill the values of aqidah for children is not by the ability to argue, but by keeping children busy by reading the Koran and its interpretations, reading the hadiths and their meaning, and making them 
busy doing various worship activities. This learning can be categorized as a demonstration method, which puts forward demonstrations or shows to students a certain process, situation, or object being studied accompanied by oral explanations (Siregar \& Nara, 2010).

There is no doubt that the teaching of the Koran is an effort to build good character. Eliminating ignorance through the process of transferring manners and a responsible human character (Retnaningrum, 2018). IImam Suyuti said that "teaching the Koran to children is one of the pillars of Islam so that they can grow above the nature and light of wisdom before lust overcomes them and before being tainted by immorality and error." This is reinforced by Ibn Khaldun (2000, p. 759) that teaching children to learn about the Koran is Islamic syiar and character practiced by scholars. Muslims own the Koran and practice its teachings. Making it teaching will inspire the heart with faith and reinforce belief in the Koran and Alhadis. The Qur'an becomes the basis for teaching and becomes the foundation for all skills that are acquired later. Because, the things that are taught to a child will have deeper roots than anything else, and become the basis for all knowledge that is acquired afterward.

Teaching the Koran can lead them to a belief that Allah SWT is their God and the Koran is His word, so that the spirit of the Teaching the Koran can foster faith in Allah. When children accept the aqidah of the Koran from childhood, when they grow up they will love the Koran more, feel a close connection with it, fulfill all commands and stay away from Allah's prohibitions, have the character of the Qur'an and walk according to the path (Suwaid, 2006, p. 192). Religious education through the Koran is the main foundation that guides children to be competent in the emotional, social, and intellectual skills of children in the future. One method of instilling the value of faith in early childhood is by teaching the Koran from the introduction of hijaiyah letters. Research conducted by Islamiah, et al (2019) confirms that hijaiyah letters can be introduced since children aged 6 months. They made them by using used cardboard and origami paper with large sizes then taped so that they are easily seen by children. Furthermore, every day sounding the hijaiyah letters randomly to stimulate the senses has made children smarter in memorizing the Koran and has a noble character.

Another method for instilling the value of aqidah is through singing. This is because music is very influential in improving complex children's abilities. A singing method is a learning approach that can actually make children happy and have fun. Children are directed to psychological situations and conditions to build a happy spirit, enjoy the beauty, develop feelings through words and tones, as well as rhythms that beautify the learning atmosphere. Of course, it must be used as a means of effective communication for educational purposes as much as possible (Aryani, 2015). Many songs can be sung which contain the names of Allah and His creations around the child's life, the names of angels, the stories of the Prophet and the apostles, the pillars of faith, songs about life skills and others that are suitable for children. . Singing songs that match the learning theme gives joy and happiness to children in learning. Joy and happiness play an important and influential role in the mental development of children. Children's joy will create a sense of optimism and self-confidence so that children will always be ready to receive orders, warnings or instructions from parents or other adults (Sholeh, 2018). 
An appropriate learning strategy is selected and used by a teacher to deliver learning material, making it easier for students to achieve learning goals (Siregar \& Nara, 2010), such as taking advantage of certain situations to ask questions to children to improve their faith. For example, during a field trip to the park, the teacher can ask a lot of questions about who created water, trees, and others, to arouse children's attention to the greatness of Allah. This is where a teacher Raudhatul Athfal must be able to appear as a teacher with a variety of roles according to the characteristics and uniqueness of students. So those children will be able to play a role and develop optimally.

Teaching aqidah for early childhood is to maintain the nature of their faith. Children should be turned on by their passion for truth and religion. At an early age, there should not be any burden that will traumatize or damage their fitrah. The teaching method by telling stories or telling stories in the Koran is very good to be applied. Storytelling activities can optimize the development of children's religious and moral values, these are values to create a child to have a religious character (Wahyuni \& Purnama, 2020). Therefore, his subconscious will be filled with positive imaginations about Allah, angels, books, messengers, the Last Day, and His qadha.

The second is material on worship guidance. Worship is a reflection of aqidah when a child fulfills the call of his Rabb and carries out his orders. It means welcoming the innate tendencies of his soul. In the context of religious education, for early childhood, it is not an imposition or giving of obligations but rather preparation, training and habituation to welcome the period of imposition of obligations (taklif) when they reach maturity (Suwaid, 2006). Learning through practice is an effective method and is considered important to be applied to early childhood. In other languages, it is called learning by doing. This will make an impression in the soul of children, strengthen the knowledge in the heart and strengthen it in the memory. Among the things that can be trained for early childhood are; how to brush teeth, practice washing hands properly, practice ablution, say greetings when entering the house, practice reading prayers when starting activities (Aryani, 2015).

Learning through practice has been exemplified by Rasulullah SAW as the first and foremost Islamic educator. This practice has proved to be encouraging for the development of Islam among friends. In many ways, the prophet always taught something accompanied by his practice. For example procedures for purification, ablution, performing prayers, doing pilgrimage, and fasting (Sholeh, 2018). Learning through practicing worship exercises will sharpen children's motor function from an early age. Later, they will have the correct awareness to carry out worship in accordance with Islamic teachings. Become an obedient human being to carry out all the commands of Allah and stay away from all His prohibitions when the child reaches aqil baligh. Worship as the realization of the Islamic creed must be practiced properly by every believer.

The third is the material on building akhlaqul karimah (noble behavior). Moral education aims to foster future generations with noble characters, namely the effort to instill praiseworthy behaviour from an early age both to God, to oneself and the family environment, and the natural surroundings. Learning morals for early childhood also aims to avoid disgraceful morals. Learning morals through practice, habituation, and role models from family members, especially parents. Because what children receive and 
experience from an early age will stick with them and will shape their personality (Aryani, 2015). A personality that is formed from cultivating good morals will prepare a child to become a responsible person with noble morals when he grows up.

Another method is habituation and modelling. Both are learning methods that are considered effective for early childhood. If children are always accustomed and exemplified by good behaviour, they will have a tendency to do good until they are adults and even old. Methods through habituation and activities will also affect early childhood character development (Suyanto, 2015). This happens because the values of goodness have been embedded into his mindset, attitude, and behaviour.

To apply these learning tasks more creatively, every teacher is highly required to have competence in the learning process, so that the expected goals or objectives are achieved in the learning process. Teaching competence is one of the most important teacher qualifications. Teachers must be able to meet the competencies expected by the community and students in carrying out learning (Manizar, 2018). The role of the teacher as a facilitator is important to remain a source of exemplary inspiration for students.

Parents also have a central role in instilling good etiquette values for early childhood. This was exemplified by our prophet; Rasulullah saw when he gave such great attention to the process of moral formation. The activity of cultivating adab in children and their habituation to become daily habits is more important than alms which can dissolve mistakes. Narrated from At-Turmudzi from Jabir Ibn Samrah r.a, Rasulullah saw said which means "A person who teaches manners to his child, it is better for him than one sha alms". " In another hadith narrated by Ibn Majah r.a narrated from Ibn Abbas r.a from the Prophet, PBUH, said which means "Honor and respect your children, and improve their behavior. Based on the hadith, it illustrates that early childhood children need to be close to their parents in getting good behaviour models.

Research by Amin et al. (Amin et al., 2020) proves that there is a positive and significant influence between child and mother attachment on the independence of children aged 5-6 years in kindergarten PKK Banaran, Pulung, Ponorogo. This attachment also affects the good values of a child in the future when he reaches baligh.

When children are not taught good manners, they will imitate bad behavior and manners. From bad manners, you will get a breakdown of thought patterns, which lead to bad habits and temperament, so that bad deeds will occur (Suwaid, 2006). The consequence is that when someone has reached puberty, they do not have the awareness to carry out the orders to leave the prohibitions of Allah SWT. It even gave birth to a number of behaviors that deviate from religious teachings. Character education is very important given from an early age. Moral education is not only in the form of subjects but inculcates human values, dignity, moral values, character, and ultimately the formation of a person with a personality must be carried out in everyday life. The most influential method in instilling character in early childhood is by providing examples that can educate children about the character (Aryani, 2015). Exemplary from parents and teachers is the key to the success of good moral formation.

The role of teachers in character education is very important. Not only teaching children to recognize the character but also setting good examples. As well as educating 
children by practicing good deeds because children like to model what their teachers do (Suyanto, 2015). The role of parents is also very central for early childhood. Teachers and parents should encourage when children do a good thing. On the contrary, if a child does something bad, parents and teachers should immediately prevent, warn and explain the consequences of the actions taken so that the child understands and understands the mistakes he/she is making (Retnaningrum, 2018). Parents and teachers in providing education should pay attention and always follow the child's development in fostering aqidah and morals as well as preparing the child's spiritual and social. It is very important to understand that the nature of development at the age of 0-7 years, children are at a time when imagination and abstraction are at their peak. His subconscious is still wide open, so that images about Allah, about Rasulullah, about virtue, about his creation will easily be awakened at this age. Of course not through doctrine or cognitive formality, but through positive and beautiful images, for example through an inspirational story about the passion for the nobility of character, the spirit of heroism, the spirit of brotherhood between humans, the morals of the Prophet and his friends and so on (Santosa, 2018).

Moral learning is integrated into learning materials for aqidah and ibadah. Its nature is not just routine but in various daily activities. This has an influence on the motor sensor which develops according to the nature of the faith. His moral nature includes cultivating affection for others, responsibility, courtesy, cleanliness, and neatness and order in the rules.

\section{CONCLUSION}

Learning aqil baligh is a set of conscious actions and efforts from both parents and Raudhatul Athfal or kindergarten teachers to provide understanding and readiness of students to take responsibility when they reach adulthood. There are three important materials to instill values and shape the character of aqil baligh. They are the material for fostering aqidah, material about ibadah as a continuation of the development of aqidah and the material for building akhlaqul karimah (noble behavior). This moral material aims to prepare a child when he reaches maturity, avoiding despicable behavior that must be done from an early age, through training, habituation, and good examples from family members, especially parents and teachers.

The teaching method for early childhood in instilling these three values is by doing lots of physical activities such as singing, telling stories, practicing to get used to it, habituation and modeling. The most important thing is in the process of teaching and learning aqil baligh for early childhood in building aqidah, ibadah and akhlaq to prepare children's spiritual and social skills through open imaginative activities.

\section{REFERENCES}

Adzim, M. F. (2005). Positive Parenting, Asyik Jadi Orang Tua Bagi Para Ayah. Pro-U Media.

Al-Ghazali, I. (2020). Ihya 'Ulumuddin Biografi Imam Al-Ghazali, Ilmu, Iman (I. Kurniawan (ed.); Revisi II). Penerbit Marja.

Amin, M., Kristiana, D., \& Fadlillah, M. (2020). Pengaruh Kelekatan Aman Anak pada Ibu terhadap Kemandirian Anak Usia 5-6 Tahun. Jurnal Obsesi : Jurnal Pendidikan Anak 
Usia Dini, 5(1), 127. https://doi.org/10.31004/obsesi.v5i1.504

Aryani, N. (2015). Konsep Pendidikan Anak Usia Dini Dalam Perspektif Pendidikan Islam. Potensia: Jurnal Kependidikan Islam: Jurnal Kependidikan Islam, 1(2), 213-227. https://doi.org/10.24014/POTENSIA.V1I2.3187

Aynun, N. (2018). Mendidik Anak Pra-Aqil Baligh. PT. Elek Media Komputindo.

Bahfen, M., Khaerunnisa, Hadi, M. S., Madyawati, L., \& Sulistyaningtyas, R. E. (2020). Improving Number Ability Through Demonstration Method in Children Aged 4-5 Years. 1st Borobudur International Symposium on Humanities, Economics and Social Sciences (BIS-HESS 2019), 436, 1099-1101. https://doi.org/10.2991/assehr.k.200529.230

Fadlullah. (2017). Pendidikan Anak Usia Dini dalam Perspektif Islam. Ta'dib: Jurnal Pendidikan Islam, 6(2), 65-74. https://doi.org/10.29313/tjpi.v6i2.3195

Hidayat, B., Putra, A. A., \& Harahap, M. (2018). Pendidikan Anak Usia Dini Menurut Psikologi Islami. Generasi Emas: Jurnal Pendidikan Islam Anak Usia Dini, 1(1), 29-38. https://doi.org/10.25299/ge.2018.vol1(1).2254

Islamiah, F., Fridani, L., \& Supena, A. (2019). Konsep Pendidikan Hafidz Qur'an pada Anak Usia Dini. Jurnal Obsesi: Jurnal Pendidikan Anak Usia Dini, 3(1), 30. https://doi.org/10.31004/obsesi.v3i1.132

Jasuri. (2015). Pembelajaran Pendidikan Agama Islam Pada Anak Autis. Madaniyyah, VIII, $16-31$.

Khaldun, I. (2000). Muqaddimah Ibn Khaldun (A. Thoha (ed.); Terjemahan). Pustaka Firdaus.

Khallaf, A. W. (2002). Kadah-kaidah Hukum Islam; Ilmu Ushulul Figh. Raja Grafindo Persada.

Langgulung, H. (2004). Manusia \& Pendidikan Suatu Analisa Psikologis, Filsafat dan Pendidikan. Pustaka Al-Husna Baru.

Manizar, E. (2018). Optimalisasi Pendidikan Agama Islam di Sekolah. Tadrib: Jurnal Pendidikan Agama Islam, 3(2), 251-277. https://doi.org/10.19109/tadrib.v3i2.1796

Muhadjir, N. (1996). Metodologi Penelitian Kualitatif (Cet. ke-7).

UU No. 20 Tahun 2003 Tentang Sistem Pendidikan Nasional, Pub. L. No. UU No. 20 tahun 2003 (2003).

Pires, C. D. A. (2018). Pendidikan Anak Usia Dini. Researchgate.

Retnaningrum, W. (2018). Pendidikan Karakter Bagi Anak Usia Dini Perspektif Islam. Jurnal Warna, 2(2), 56-68.

Rizal, H., \& Zuhri, S. (2006). Pemikiran Al-Ghazali tentang pendidikan akhlak. Suhuf, XVIII(02), 166-181.

Salati, H. S. (2012). Konsep Pendidikan Anak Usia Dini Menurut Islam. Tarbiyah Islamiyah: 
Jurnal Ilmiah Pendidikan Agama Islam, 2(1). https://doi.org/10.18592/JT IPAI.V2I1.1868

Santosa, H. (2018). Fitrah Based Education: Sebuah Model Pendidikan Peradaban bagi Generasi Peradaban Menuju Peran Peradaban (R. Dwi DM (ed.); Cet.VI). Yayasan Cahaya Mutiara Timur.

Sholeh, M. (2018). Pendidikan Anak Usia Dini Dalam Perspektif Pendidikan Islam. Yinyang: Jurnal Studi Islam Gender Dan Anak, 13(1), 71-83.

Siregar, E., \& Nara, H. (2010). Teori Belajar dan Pembelajaran (A. Jamaludin (ed.)). Ghalia Indonesia.

Suradi, A. (2018). Sistem Pendidikan Anak Usia Dini Dalam Konsep Islam (Analisis dalam Teoritis dan Praktis). Al-Athfal: Jurnal Pendidikan Anak, 4(1), 61-84. https://doi.org/10.14421/al-athfal.2018.41-05

Susiba, S. (2019). Pendidikan Akidah Bagi Anak Usia Dini. Potensia: Jurnal Kependidikan Islam, 4(2), 155. https://doi.org/10.24014/potensia.v4i2.5871

Suwaid, M. I. A. H. (2006). Cara Nabi Mendidik Anak (A. Hakim \& Suratno (eds.); Terjemah). Al-I'tishom Cahaya Umat.

Suyanto, S. (2015). Pendidikan Karakter untuk Anak Usia Dini. Jurnal Pendidikan Anak, 1(1). https://doi.org/10.21831/jpa.v1i1.2898

Wahab, W. (2018). Implementasi Pendidikan Agama Islam Pada Pendidikan Anak Usia Dini (PAUD). Pusaka, 6(1), 79-92. https://doi.org/10.31969/pusaka.v6i1.39

Wahidah. (2020). Reaktualisasi pendidikan aqil baligh di sekolah. At- Tarbawi, 12(2), 189202. https://doi.org/10.32505/tarbawi.v12i2.2036

Yahya, M., \& Rahman, F. (1986). Dasar-Dasar Pembinaan Fiqh Islami. Alma'arif.

Zulfa. (2014). Implementasi Kurikulum dan Strategi Pembelajaran Pendidikan Agama Islam pada PAUD. Mudarrisa: Jurnal Kajian Pendidikan Islam, 1-29. 